\title{
KEPEMIMPINAN INOVATIF DALAM PELAKSANAAN PROGRAM SWASEMBADA PANGAN NASIONAL DI KABUPATEN BONE
}

\author{
Ali Anas ${ }^{1}$, Muh. Tang Abdullah ${ }^{2 *}$ \\ 1Program Studi Administrasi Publik, Sekolah Tinggi Ilmu Administrasi PRIMA Bone \\ 2Program Studi Administrasi Publik, Universitas Hasanuddin Makassar \\ *) Korespondensi: mtapublikunhas@gmail.com
}

Article Histori:

Accepted: $18 / 7 / 2021$

Review: 4/10/2021

Publish: 31/10/2021
Abstract

This study aims to analyses innovative leadership in increasing national food selfsufficiency through the Direct Seed Planting Equipment (ATABELA) program in Bone Regency. Methods This research uses a qualitative approach and case studies. Data were collected through interviews, observations, and documented data. Informants consist of key and secondary informants. The results of the study found that in strategic planning, the Regent was very active in socializing the ATABELA innovation program, involving stakeholders, the source of innovation came from the Regent's leader and then instructed to the Department of Agriculture. There is collaboration in the implementation of ATABELA innovations. And in terms of the Regent's leadership commitment, it has not been supported by special regulations in the form of regional regulations on innovation, but leadership commitment has been very visible in this ATABELA innovation program and the support of DPRD members from the Golkar party. Leadership commitment is determined by the personal character of the Regent who is hard and has a high willingness to innovate to increase national food self-sufficiency with the ATABELA program. Furthermore, the stability of leadership in the implementation of innovation with dedication starting from career officials, becoming Deputy Regents, expert staff for the Governor of South Sulawesi and in the end being elected as Regent with this capital and experience then strongly supports ideas and knowledge about regional characteristics of Bone Regency to carry out innovations.

Keyword: ATABELA, innovative, leadership.

\section{PENDAHULUAN}

Dalam perkembangan inovasi di sektor publik sangat ditentukan oleh kapasitas dan kualitas kepemimpinan dalam mendorong pelaksanaan inovasi. jejak literasi dalam administrasi publik, inovasi sektor publik yang menuntut adanya proses adaptasi terhadap kemajuan dan perkembangan masyarakat melalui new public management dengan menagdopsi pola swasta untuk merangsang kompetitif para-administrator secara efektif dan efisien. Inovasi pada umumnya identik pada sektor bisnis dengan karakteristik organisasi yang cenderung lebih dinamis jika dibandingkan dengan sector publik. Kapasitas inovasi dalam sektor publik, menurut Gabries, et al (2009: 23-24), bahwa dalam mengelola inovasi sangat ditentukan oleh tiga kunci faktor strategis (three core startegic factors) yaitu: Pertama, pemimpin yang kredibel (leadership creadiblity).

Pemimpin yang memiliki kredibilitas adalah pemimpin yang memiliki keterampilan dan perilaku yang dapat dipelajari, dipraktekkan dan digunakan untuk mencapai kinerja organisasi yang tinggi. Pemimpin yang kredibel adalah pemimpin yang memiliki visi yang jelas, yang menjadi arah kemana organisasi melangkah. Visi seorang pemimpin disini juga

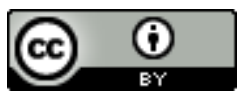


harus dikomunikasikan ke bawahan untuk diikuti dan diwujudkan bersama; Kedua, faktor adanya tim manajemen yang kuat (strong management teams). Tim manajemen yang kuat dalam konteks ini adalah struktur birokrasi pemerintah daerah yang profesional, yang bekerja menurut fungsi dan tugas masingmasing unit. Struktur manajemen birokrasi harus bekerja secara efisien, mengambil keputusan secara rasional dan bekerja berdasarkan spesialisasi masing-masing.

Kemudian faktor strategis; Ketiga adalah berfungsinya badan-badan pemerintahan (governing board functioning). Dalam konteks ini yang dimaksud adalah bekerjanya lembaga perwakilan warga (council city) dalam merumuskan kebijakan-kebijakan strategis, seperti rencana strategi pembangunan, kebijakan tentang pengalokasian anggaran dan menyusun solusisolusi atas persoalan masyarakat tanpa membeda-bedakan (diskriminasi).

Berdasarkan data awal yang dikumpulkan oleh peneliti menemukan bahwa tahun 2016 luas tanam padi di Kabupaten Bone sebesar 241.945 Ha, meningkat 98.590 Ha dari 143.355 Ha pada tahun 2013. Peningkatan ini juga disusul dengan peningkatan luas panen padi dari $131.035 \mathrm{Ha}$ pada tahun 2013 meningkat hingga $182.209 \mathrm{Ha}$ pada tahun 2016, meningkat sebesar 51.871 ton. Data peningkatan luas tanam dan luas panen ini di ikuti dengan peningkatan produksi padi sebesar 281.081-ton dari 777.731-ton pada tahun 2013 hingga mencapai 1.058.812-ton pada tahun 2016, atau meningkat sebesar $36.14 \%$ dalam kurun waktu 3 tahun. Selanjutnya dapat dilihat pada tabel berikut ini

Tabel 1. Peningkatan Produksi Pertanian/ Lahan

\begin{tabular}{cccc}
\hline Tahun & Luas areal tanam & Produksi (Ton) & Produktivitas (Kw/Ha) \\
\hline $\mathbf{2 0 1 3}$ & 143,355 & 131,035 & 59,353 \\
$\mathbf{2 0 1 4}$ & 170,791 & 155,883 & 56,81 \\
$\mathbf{2 0 1 5}$ & 155,364 & 170,359 & 57,714 \\
$\mathbf{2 0 1 6}$ & 241,945 & 182,906 & 57,888 \\
\hline
\end{tabular}

Sumber : Dinas pertanian Kabupaten Bone, 2017

Dari tabel diatas menunjukkan bahwa terjadi masalah dalam peningkatanjumlah luastanam, luas panen dan pertambahan hasil panen berbanding terbalik dengan data produktivitas padisetiap tahun. data sektor pertanian Kabupaten Bone tahun 2017 produktivitas padi malah stagnan, atau meskipun kecil, malah bisa dikatakan mengalami penurunan tercatat, data produktivitas padi pada tahun 2013 sebesar $59.353 \mathrm{kw} / \mathrm{Ha}$, disusul $56.801 \mathrm{kw} / \mathrm{Ha}$ pada tahun $2014,57.714 \mathrm{kw} /$ ha pada tahun 2016, hingga di tutup pada angka produktivitas $57.888 \mathrm{Kw} / \mathrm{Ha}$ pada tahun 2016. Data tersebut sangat paradox dengan fakta bahwa alokasi anggaran untuk sektor pertanian meningkat setiap tahun yaitu $\mathrm{Rp}$. 16.606.778.338 (2013), Rp. 20.147.862274 (2014), Rp.22.910.296.468 (2015) dan Rp. 26.034.706.655 pada tahun 2016.

Fakta kondisi pertanian terkhusus sektor produksi padi merupakan ironi dengan adanya sederat daftar penghargaan yang diterima oleh pemerintah Kabupaten Bone mengenai inovasi di bidang pertanian. Perlu sedikit ditekankan dalam konteks penelitian adalah bahwa di Kabupaten Bone sendiriterdapat programyang telah diganjar dengan penghargaan inovasi menurut kementerian pertanian pada tahun 2015 yaitu perubahan atas program tanam benih langsung (ATABELA), yaitu program pemerintah yang merubah pola pikir masyarakat dalam manajemen sistem tanam, dari yang sebelumnya menggunakan model tanam hambur menjadi sistem tanam pindah sehingga dari gambaran atas data yang ada tersebut kemudian menjadi alasan yang menarik untuk melakukan penelitian terkait dengan kepemimpinan inovatif dalam pelaksanaan inovasi peningkatan swasembada pangan nasional melalui program ATABELA. 
Dengan melakukan penelitian terhadap kapasitas kepemimpinan inovasi yang dilakukan oleh pemerintah daerah Kabupaten Bone menurut Kim (2007) bahwa kapasitas kepemimpinan inovatif dapat dilihat dari beberapa indikator: seperti perencanaan strategi; komitmen kepemimpinan; dan stabilitas kepemimpinan; sangat di perlukan.

\section{KAJIAN LITERATUR}

World Bank (2006) mencatat penerapan inovasi pada sector public secara desentralisasi sangat ditentukan oleh kepemimpinan lokal dalam menyediakan pelayanan publik yang inovatif. Inovasi yang di lakukan oleh pemerintah daerah cenderung tidak di dukung oleh peraturan tingkat pusat tetapi kewenangan desentralisasi kepada pemerintah daerah dengan beberapa urusan pokok. Kewenangan ini kemudian akan lebih memberi keleluasaan bagi pemimpin local untuk mengatur administrasi dan keuangan dalam mendanai kegiatan inovasi secara lokal. Idealnya setiap inovasi yang dilakukan oleh pemerintah daerah mendapat dukungan dari stakeholder's yang ada di tingkat kabupaten dan kota, hal ini dikarenakan setiap inovasi akan mengalami kesulitan jika tidak mendapat dukungan terutama dari masyarakat, politisi serta DPRD kabupaten dan/kota.

Abdullah et al. (2016) mengatakan bahwa penomena inovasi pada pemerintah provinsi gorontalo, kabupaten sragen, serta kabupaten jembrana merupakan pelajaran yang sangat bernilai, arena pada daerah tersebut kapasitas pemeritah daerah dalam melakukan inovasi di daerahnya sangat berkorelasi positif dengan dukungan masyarakat terhadap pemerintah daerah masing-masing. Sementara Muhammad (2007) mengatakan bahwa permasalahan dalam melakukan inovasi pada tingkat lokal adalah persoalan pemimpin, kepemimpinan harus mendorong perubahan. Pemimpin yang memiliki komitmen yang jelas akan mendorong pengikutnya untuk mewujudkan visi tersebut melalui daya kreatif dan daya inovasi yang dimilikinya. Pemimpin yang yang punya visi tentu belum cukup apabila tidak ada kemauan politik dan tanpa kemauan politik pemimpin akan mengalami kesulitan melakukan inovasi.

Lebih lanjut menurut pandangan Borins (2001) yang mengatakan bahwa munculya new leadership yakni pemimpin akan membawa ide-ide dan konsep-konsep baru, bisa berasal dari eksternal atau internal organisasi tesebut. Dari pandangan Borins (2001) mengatakan bahwa praktek inovasi akan sangat ditentukan oleh pemimpin. Kemudian Watson (1997) masalah-masalah tingkat local (local problems) melalui innovative government: creativesapproach to local problems. Yang mengatakan bahwa reason local governments can be innovative is that there are so many of them doing basically the same things. Each community serves as a laboratory for innovation. ......, local governments to solve problems and develop solutions in different ways. Kemudian UNDESA (2006) mengatakan bahwa inovasi terdiri dari new products, new policies and programs, new approaches, and new processes. Dalam teori pengembangan kapasitas menurut Grindle (2007) melalui karya Getting Good Government: Capacity Building in the Public Sector of Developing Countries. Mengatakan bahwa kapasitas dapat dilihat dari dimensi 1. Human resources: 2. Organizational strengthening; 3. Institutional reform.

Sejalan dengan Keban (2009) yang terdiri atas (1) Individu;, (2) Organisasi dan; (3) Jejaring. sangat relevan dengan kajian pengembangan kapasitas inovasi sebab sebaik apapun sebuah inovasi tentu tidak akan dapat berjalan tanpa keterlibatan peran indvidu dalam organisasi dengan jejaring yang kuat antar organisasi terkait. Selanjutnya kajian pengembangan kapasitas kepemimpinan inovasi menurut Gabries et. 
al (2009) dan Savira (3017) bahwa dalam mengatur sebuah inovasi akan sangat ditentukan oleh 1). Leadership credibility dimana pemimpin yang memiliki keterampilan dan perilaku yang dapat dipelajari, di praktekkan dan di gunakan untuk mencapai kinerja organisasi yang tinggi.

Pemimpin yang kredibel adalah pemimpin yang memiliki visi yang jelas, yang menjadi arah kemana organisasi melangkah. Visi seorang pemimpin dalam hal ini juga harus dilakukan komunikasi ke level bawah untuk diikuti dan diwujudkan bersama. 2). Strong management teams. Tim manajemen yang kuat dalam konteks ini adalah struktur birokrasi pemerintah daerah yang profesional, yang bekerja menurut fungsi dan tugas masing-masing unit. Struktur manajemen birokrasi harus bekerja secara efisien, mengambil keputusan secara rasional dan bekerja berdasarkan spesialisasi masing-masing.

Kemudian faktor strategis 3). berfungsinya badan-badan pemerintahan (governing board functioning) dalam Abdullah et al (2016). Sementara Kim, et al (2007) dalam studi kapasitas inovasi pemerintah daerah di Korea Selatan dengan a model of management capacity and government innovation melalui salah satu dimensinya yakni kepemimpinan inovatif yakni kepemimpinan yang mmemiliki kemauan dan kemampuan untuk melakukan inovasi dengan komitmen untuk menjaga stabilitas dalam menyebarkan budaya inovasi dalam lokal pemerintahan.

\section{METODE PENELITIAN}

Metode penelitian ini adalah dengan menggunakan pendekatan kualitatif melalui observasi, dokemntasi terkait inovasi dalam program ATABELA serta wawancara secara langsung. dengan kajian tentang pengembangan kapasitas kepemimpinan inovatif dalam peningkatan swasembada pangan nasional di
Kabupaten Bone. Untuk memberi gambaran deskripsi terhadap perencanaan strategis, komitmen kepemimpinan dan stabilitas kepemimpinan yang dilakukan oleh pemerintah daerah kabupaten Bone.

Dalam pelaksanaan inovasi program ATABELA pada organisasi perangkat daerah yang, seperti kepala dinas pertanian, kepala badan ketahanan pangan, kepala BMKG, aparat berwajib, masyarakat dan penyuluh pertanian dalam mendukung program inovasi yang dicanangkan oleh Bupati, dengan model spiral Cresswel (2002) yang kemudian data yang ada dilakukan koding sesuai dengan hasil wawancara, kajian literatur terkait dan juga dokumentasi berdasakan observasi secara langsung pada lokus penelitian sesuai dengan dimensi pengembangan kapasitas kepemimpinan inovatif dalam peningkatan swasembada pangan nasional di Kabupaten Bone.

\section{HASIL DAN PEMBAHASAN}

Kapasitas strategis perencanaan Kepemimpinan inovasi merupakan kajian yang sangat sulit untuk dipisahkan dari konteks inovasi, sebab kepemimpinan yang dimiliki seseorang dalam melakukan inovasi menyangkut kemampuan untuk mengembangkan inovasi dalam organisasi tertentu selain itu kemampuan itu juga di tunjang dengan wawasan pengetahuan yang luas Meskipun penelitian tentang kepemimpinan bagaimana ia mempengaruhi inovasi adalah salah satu fenomena yang paling dapat diamati sebagai objek penelitian kapasitas kepemimpinan inovasi di ukur dari komitmen dan kemauan politik guna memberi pelayanan yang baik kepada warganya, dari penelitian yang dilakukan dilapangan.

\section{Perencanaan Strategis}

Perencanaan strategis Bupati Bone dalam melakukan inovasi nampak begitu kuat sebab sejak menjabat sebagai wakil Bupati Bone periode 2003-2008, kemudian 2009 menjadi staf ahli gubernur dan pada 
tahun 2013 terpilih menjadi Bupati Kabupaten Bone. Andi Fahsar M Padjalangi bersama dengan Ambo Dalle masingmasing sebagai Bupati dan Waki BUpati Bone telah mencanangkan Inovasi di bidang pertanian melalui program ATABELA 2014. Artinya setahun setelah dilakukan pelantian sebagai Bupati dan Wakil Bupati mereka mendorong Kabupaten Bone mendukung swasembada pangan Nasional. Dalam literatur, kapasitas kepemimpinan telah dipahami sebagai masalah kepribadian seseorang (Political Will) kapasitas tersebut di dukung dengan Sumbedaya Manusia yang mumpuni Kim, (2007).

Kepemimpinan inovasi sebagai sebuah proses dalam mempengaruhi organisasi untuk memahami dan menyetujui tentang apa yang perlu dilakukan inovasi ATABELA secara efektif, dengan mendorong setiap OPD terkait dalam setiap pertemuan untuk melaksanakan program inovasi ATABELA. Terdapat fakta bahwa karakter kepemimpinan inovasi dari Bupati Bone jika dilihat dari cara mengontrol dan mengendalikan inovasi ditemukan beberapa langkah strategis dalam melakukan inovasi yang berbeda dengan teori Kim yang meliputi adanya control, monitoring dan instruksi yang berlebih, menekankan pada struktur birokrasi serta Memberikan kerangka kerja melalui ekspansi kewenangan untuk pengambilan keputusan dan tindakan yang menjadi ciri dari kepemimpinan direktif, terdapat kebebasan untuk mengembangkan solusi yang mencirikan kepemimpinan partisipatif, memberikan contoh pribadi, proyeksi visi dan keterlibatan langsung sebagai indikasi kepemimpinan kharismatik, memberikan punishment dan reward yang memberikan indikasi kepemimpinan transaksional

\section{Komitmen Kepemimpinan}

Komitmen inovasi Bupati Bone Nampak dengan memfasilitasi upaya individu dan kolektif untuk mencapai visi
Mandiri Berdaya Saing (MABESSA) bersama Wakil Bupati mendoroang OPD terkait untuk melakukan inovasi terutama Dinas Pertanian sebagai leading sector dalam inovasi ATABELA. mengembangkan sebagai alternatif untuk meningkatkan hasil pproduksi pertanian di Kabupaten Bone bentuk kepemimpinan dimana sistem komando dengan mengintervensi melalui kewenangan untuk mencapai swasembada Pangan Nasional melalui Inovasi ATABELA.

Fakta menunjukkan bahwa komitmen kepemimpinan penting dalam kapasitas manajemen inovasi yang pada akhirnya memainkan peran yang menentukan dalam meningkatkan kreativitas organisasi untuk melahirkan dan mengarahkan inovasi ATABELA kemudian mengimplementasikannya dengan mengatasi resistensi yang muncul dalam prosesnya. Pemimpin inovatif adalah pendorong utama, yang baik mempromosikan atau menghambat manajemen program inovasi ATABELA dalam di Kabupaten Bone. Sejalan dengan pendapat menurut Borins (2000) pemimpin inovasi cerdik dalam berinisiatif, politisi yang berkuasa serta kemampuan untuk memanipulator untuk kepentingan pibadi hal ini sejalan dengan Bupati Bone bahwa ia dapat melakukan inovasi dengan legitimasi kekuasaan yang dimiliki.

Dari hasil penelusuran penelitian ini bahwa ternyata Sumber inovasi dari pemimpin sejalan dengan Kim (2007) bahwa kapasitas manajemen inovasi Pemerintah daerah di inisiasi oleh pemimpin atau Bupati. Sementara itu Pemimpin inovasi memiliki gambaran mengenai masalah pokok dalam sektor pertanian terutama produktivitas hasil pertanian dan memiliki strategi dalam melakukan inovasi dengan melakukan eksvansi kewenangan dengan melibatkan pihak Tentara Nasional Indonesia (TNI) untuk melakukan 
pengawasan, Bupati Bone sebagai pemimpin Inovasi memiliki.

Komitmen yang kuat dalam melaksanakan inovasi dimana Semakin keras watak pemimpin semakin kuat komitmen Semakin jelas analisis resiko semakin bisa diperkecil resiko tersebut maka semakin berkomitmen pemimpin inovasi Semakin berkomitmen pemimpin maka semakin sering terlibat langsung Semakin berkomitmen pemimpin inovasi maka semakin luas saluran komunikasi yang dibentuk tidak ada aturan yang spesifik namun mendorong kolaborasi lintas OPD dan memberikan penekanan melalui peraturan terpisah dalam memaksimalkan program masing-masing OPD untuk berkontribusi dalam kseuksesan inovasi ATABELA Inovasi merupakan hal yang urgen untuk dilaksanakan sesuai dengan persepsi dari pemimpin inovasi, dalam hal ini dipengaruhi oleh kewenangan dan lamanya kewenangan tersebut diperoleh.

\section{Stabilitas Kepemimpinan}

Fakta tentang stabilitas kepemimpinan Bupati Bone dari hasil penelitian penulis mengambil kesimpulan bahwa semakin lama kewenangan didapatkan maka akan tercipta stabilitas kepemimpinan dan semakin cepat langkah inovasi diambil. Inovasi ATABELA menjadi program unggulan dalam pembangunan pertanian di Kabupaten Bone sehingga mengantarkan Bupati Bone menjadi Bupati Inovatif dalam bidang pembangunan Pertanian, sesuai dengan komitmen visi dan misi pengembangan inovasi, langkah-langkah strategis guna mendorong lahirnya inovasi. Walaupun komitmen tersebut belum berbentuk regulasi tetapi dengan kewenangan yang dimiliki Bupati Bone mengintruksikan kepada OPD terkait untuk melaksanakan inovasi ATABELA. Ini dilakukan untuk mempercepat swasembada pangan di Kabupaten Bone. Selanjutnya Fakta hasil kajian Kepemimpinan Bupati Bone dalam pelaksanaan program inovasi ATABELA dengan mencetuskan ide, hal ini relevan dengan Kim, (2007) bahwa ide inovasi muncul dari pemimpin inovatif. Demikian pula Kim (2015), Evans (2010) sejalan dengan penelitian Abdullah, et al (2016) yang mengkaji kapasitas inovasi pemerintah daerah melalui kasus yang berbeda menemukan bahwa (1) Kapasitas mengetahui adanya kesenjangan metode dan pemberian layanan; (2) Kapasitas membangun kemitraan dengan stakeholder yang di dukung sumberdaya; (3) Kapasitas bertindak dalam kerangka kebijakan legislative dan memanfaatkan situasi politik secara tepat; akan tetapi pada poin ini di Kabupaten Bone tidak sejalan sebab inovasi ATABELA belum di dukung oleh regulasi legislative berupa produk peraturan daerah; (4) Munculnya pemimpin yang memiliki agenda reformasi untukinovasi; (5) Dukungan politik; (6) Kolaborasi tingkat departemen dan unit pelayanan melalui komunikasi yang efektif; (7) Keterlibatan warga local; dan (8) Tersedianya teknologi baru.

Hal yang sama hasil kajian Capuno (2010) terkait pentingnya posisi para pemimpin daerah sebagai penggerak utama inovasi pemerintah daerah di Filipina kajian tersebut berjudul : Leadership and Innovation under Decentralization: A Case Study of Selected Local Governments in the Philippines. (a) di era desentralisasi yang sudah berlangsung 20 tahun, pemerintah daerah berhasil melakukan inovasi dalam berbagai sektor; (b) pemimpin daerah yang masih berkuasa (incumbent mayors) menjadi pendorong utama lahirnya ide dan suksesnya pelaksanaan program inovasi di daerahnya; (c) pemimpin yang berhasil mengembangkan inovasi sangat tergantung pada situasi lingkungan (sumber daya alam), pengetahuan, pengalaman, dan insentif yang diterima; (d) faktor kritis lain selain faktor kepemimpinan adalah faktor kelembagaan meliputi kapasitas fiskal daerah, kualitas birokrasi daerah, aparatur 
yang profesional, dan pelibatan sektor swasta.

Bupati Bone dalam memimpin inovasi yaitu kondisi tujuan yang ingin dicapai dari masing-masing tipe yang ada hasil penelitian sebelumnya menunjukkan jika Bupati Bone menitikberatkan pencapaian tujuan untuk mengeksekusi gagasangagasan. penulis kemudian menemukan dimensi selanjutnya yaitu efek yang ditimbulkan dalam kepemimpinan program inovasi ATABELA di Kabupaten Bone

\section{Karakter Kepemimpinan}

Fakta lain yang berbeda dengan penelitian yang dilakukan oleh Kim., et. al (2007) di temukan di lapangan bahwa karakter kepemimpinan Bupati Bone dalam memimpin inovasi berada pada model kepemimpinan karismatik temuan 1) Dalam model directive, menekankan pada membangun aturan yang disepakati Bersama, sementara dalam inovasi ATABELA, tidak ada aturan spesifik yang memuat nomenklatur ATABELA, hanya bertumpu pada ekspansi kewenangan masing-masing OPD pelaksana; 2) Dalam Model Charismatic, ada beberapa konsekuensi yang mengikut dan relevan dengan temuan dalam penelitian yaitu a) Terciptanya komitmen; kesetiaan dan rasa misi kolektif; b) Menghasilkan energi dan momentum untuk melaksanakan inovasi; c) Mengarahkan individu (Pelaksana) menuju tujuan baru; d) Rendahnya penyerapan informasi dari bawahan.

Fakta menunjukkan bagaimana pemimpin dalam model karismatik berpengaruh terhadap inovasi yang sedang berjalan dimana gaya dan tingkah laku keseharian dari seorang pemimpin akan terinternalisasi dalam sistem dan nilai organisasi yang kemudian bertransformasi menjadi nilai kolektif, kondisi ini dipengaruhi oleh kepercayaan yang diterima oleh pemimpin dari aparat dimana semakin karakter seorang pemimpin dijadikan Patokan nilai dari organisasi maka semakin besar komitmen aparat organisasi dalam melaksanakan inovasi. Selain hal diatas, Pemimpin yang karismatik mengubah kebutuhan, nilai, preferensi, dan aspirasi pengikut. Mereka memotivasi pengikut untuk melakukan pengorbanan pribadi untuk mencapai misi yang diartikulasikan oleh pemimpin dan "untuk melakukan di atas dan melampaui panggilan tugas". Motivasi yang ada pada pengikut pada akhirnya akan mereduksi kepentingan pribadi dan bergeser ke arah melayani kepentingan kolektif yang lebih besar.

Meskipun dari penjelasan sebelumnya dikemukakan bahwa kepemimpinan karismatik dalam inovasi mampu memunculkan rasa percaya kepada pribadi dan karakter pemimpin, alih-alih mengamini, penulis justru beranggapan bahwa model ini muncul dalam konteks pengembangan kapasitas dari kepemimpinan manajemen inovasi alat tanam benih langsung lebih banyak dipengaruhi oleh latar belakang kultural dan sejarah birokrasi yang cenderung bersifat patrimonial di Kabupaten Bone.

\section{Birokrasi Patrimonial}

Dalam pelaksanaan program inovasi ATABELA di Kabupaten Bone, juga terdapat fakta yang berbdea dengan penelitian pada pengembagan kapasitas kepemimpinan sebelumnya yaitu adanya pola Birokrasi Patrimonial di reproduksi oleh rezim orde baru setelah sebelumnya menjadi produk dari kolonialisme secara de jure dalam wilayah kerajaan, pengangkatan raja-raja dan keturunannya dalam jajaran birokrasi dilanjutkan oleh rekruitmen politik Orde Baru. Melalui partai Golkar, Bangsawan diberi legitimasi dalam kontestasi Politik dan Birokrasi. Rekam jejak birokrasi, politik dan kultural dari Bupati Bone setidaknya menambah indikasi ini. Namun dalam pembahasan ini, penulis 
tidak bermaksud memberikan justifikasi terhadap benar dan salah ataupun baik buruknya nuansa patrimonial dalam pemerintah Kabupaten Bone melainkan mencoba untuk menyajikan analisis mengenai mengapa model kepemimpinan karismatik yang hadir dalam upaya Bupati Bone selaku Pemimpin Inovasi dalam mengarahkan program Inovasi ATABELA yang sedang berjalan dan hubungannya dengan internalisasi nilai kolektif dalam organisasi.

Budaya birokrasi patrimonial merupakan suatu gejala budaya yang sulit dipisahkan dengan birokrasi Indonesia. Ia merupakan suatu hasil proses sejarah, tradisi, dari zaman kerajaan tradisional, kekuasaan kolonial dan birokrasi Indonesia kontemporer yang walaupun secara struktural telah diadakan perubahan-perubahan dalam rangka menuju birokrasi yang legal rasional namun secara cultural nilai-nilai birokrasi tradisional masih tetap eksis mewarnai birokrasi pemerintahan dalam berbagai ekspresi yang baru.Fakta peneitian mengenai pengaruh Patrimonalisme sendiri merujuk pada model kekuasaan yang sentralistik dan berpusat pada penguasa perseorangan tertentu yang mengakumulasikan kekuasaan, sedangkan yang lain mengidentifikasikan kepentingannya. Penguasa membagikan sumber daya kekuasaannya kepada pihak yang dapat dipercaya dan memiliki pengaruh besar di masyarakat untuk menjaga keberlangsungan dan stabilitas kekuasaannya. Sementara, bagi pihak yang berkepentingan tersebut memiliki Aksesibilitas dalam mencari pelindungan karir, politis maupun ekonomi dalam struktur kekuasaan tersebut. Hubungan tersebut berlangsung dalam pertukaran keuntungan yang dijaga dengan rapi oleh kedua belah pihak.

Sementara itu adanya hubungan antara client (hamba) dengan patron (tuan) yang diibaratkan sebagai suatu hubungan pertukaran yang vertikal, dimana perubahan perubahan selalu berada di bawah legitimasi kaum elit. Terbentuknya relasi tersebut lebih didasarkan pada ketidaksamaan dan fleksibilitas yang tersebar sebagai sebuah sistem pertukaran pribadi. Oleh karena itulah, pola internalisasi nilai dan norma penguasa diterima meluas sehingga timbullah kekuasaan yang hegemoni yang dalam kasus birokrasi kondisi hegemoni inilah yang terinternalisasi dan berubah menjadi nilai kolektif dalam organisasi. Kondisi ini diindikasikan dengan minimnya gagasan yang bisa diserap dalam proses inovasi sehingga kadangkala pemimpin mendapat kesulitan dalam mengidentifikasi masalah teraktual yang ada dalam proses inovasi dimana penulis menangkap kecenderungan, bahwa bawahan ragu dalam melaporkan kondisi negative yang muncul dalam inovasi sebagai rasa takut dianggap gagal oleh pemimpin. Kegagalan dianggap sesuatu yang merugikan posisi tawar aparat terhadap perlindungan kekuasaan terhadap status quo yang coba dipertahankan saat inovasi terjadi dalam kondisi birokrasi yang patrimonial.

\section{PENUTUP}

Kapasitas Kepemimpinan yang ditandai dengan perencanan strategis yang sudah menyasar pada substansi masalah terlihat dari visi dan misi Bupati dan Wakil Bupati Bone periode 2013-2014, adapun sumber inovasi berasal dari Bupati Bone kemudian di instruksikan kepada Dinas Pertanian untuk melakukan inovasi pada sektor pertanian, dalam perencanaan strategis program inovasi ATABELA di Kabupaten Bone terdapat kolaborasi atau pelibatan stakeholders lain dalam pelaksanaan program inovasi ATABELA akan tetapi tidak di dukung oleh seperangkat aturan sehingga perencaan tersebut belum mencapai system kerja dalam inovasi ATABELA di Kabupaten Bones Bupati hanya menginstruksikan kepada Organisasi Perangkat Daerah untuk 
ikut terlibat dalam pelaksanaan program inovasi ATABELA.

Komitmen kepemimpinan yang tinggi oleh Bupati Bone dengan watak kepemimpinan yang keras atau kemauan yang tinggi untuk melakukan inovasi pada sector pertanian melalui program inovasi ATABELA sehingga pelaksanaan inovasi ATABELA dapat terealisasi. Dengan komitmen Bupati Bone yang kuat sehingga semakin sering terlibat dalam pelaksanaan program inovasi ATABELA sementara itu program inovasi ATABELA memiliki dampak lainnya adalah tercipta saluran komunikasi yang jelas untuk melaksanakan inovasi. Stabilitas kepemimpinan dalam pelaksanaan program inovasi ATABELA di dapatkan dengan durasi kepemimpinan yang dimulai saat menjadi Wakil Bupati Bone, menjadi staf ahli Gubernur Sulawesi Selatan hingga menjadi Bupati Bone sehingga semakin lama kewenangan itu di dapatkan menciptakan stabilitas dalam kesinambungan program inovasi.

\section{DAFTAR PUSTAKA}

Abdullah, M.T, Bambang S, MR. Khairul Muluk \& Thahjanulin. 2016. "Innovation Typology of the Local Government in Educational Affairs". BISNIS $\mathcal{E}$ BIROKRASI: Jurnal Ilmu Administrasi dan Organisasi, Vol 23, No 2 (2016). http://journal.ui.ac.id/index.php/jbb/a rticle/view/9003.

Borins, Sandford. 2008. Innovations in Government: Research, Recognition, and Replication. Washington, D.C: Brookings Institution Press.

Capuno, Joseph J. 2010. Leadership and Innovation Under Decentralization: A Case Study of Selected Local Governments in the Philippines. Discussion Paper No. 2010-10. University of the Philippines School of Economics

Creswell, JW. 2002. Research Design Qualitative and Quantitative Approaches, Alih Bahasa Nur Khabibah, KIK Press, Jakarta.
Gabris, Gerald T., Kimberly Nelson, and Curtis H. Wood. 2009. Managing for Innovation in Local Government: Three Core Strategic Factors. The Radford University Governmental and Nonprofit Assitency Centre.

Grindle, Merilee S. (Editor). 1997. Getting Good Government: Capacity Building in the Public Sector of Developing Countries. Boston, MA: Harvard Institute for International Development.

Keban, Yeremias T. 2000. Good Governance" dan "Capacity Building" sebagai Indikator Utama dan Fokus Penilaian Kinerja Pemerintahan. Naskah No.20 Team Leader Capacity Building for Local Government Bappenas.

Kim, S. E., Jung W L. \& Byong S K. 2007. The Quality of Management and Government Innovation: An Empirical Study. A paper for presentation at the 9th Public Management Research Conference, University of Arizona, October 25-27.

Kim. Soonhee \& Gyunsoo Yoon. 2015. “An Innovation-Driven Culture in Local Government: Do Senior Manager's Transformational Leadership and the Climate for Creativity Matter?". Public Personnel Management 2015, Vol. 44(2) 147-168.

https://journals.sagepub.com/doi/abs/ 10.1177/0091026014568896

Kimberly L. Nelson, Curtis H. Wood and Gerald T. Gabris. 2011. Innovation Management in Local Government: An Empirical Analysis of Suburban Municipalities. International Journal of Organization Theory and Behavior, 14 (3), 301-328.

Muhammad, Fadel. 2009. Reinventing Local Government: Pengalaman dari Daerah. Jakarta: Gramedia.

Savira, Evi Maya dan Krismiyati Tasrin. 2017. "Involvement of Local Wisdom as a Value and an Instrument for Internalization of Public Service Innovation". BISNIS \& 
BIROKRASI: Jurnal Ilmu Administrasi dan Organisasi, Vol 24, No 1 (2017). http:/journal.ui.ac.id/index.php/jbb/article/vie w/9464.

UNDESA. 2006. Innovations in Governance and Public Administration: Replicating What
Works. New York: United Nations Publication

Watson, Douglas J. 1997. Innovative Government: Creative Approach to Local Problema. London: Greenword Publishing 